\title{
The Southern Granulite Terrane: A synopsis
}

\author{
School of Earth Sciences and Resources, China University of Geosciences, Beijing, Beijing 100083, P.R. China \\ Department of Earth Sciences, University of Adelaide, Adelaide SA 5005, Australia; E-mail: santosh@cugb.edu.cn; \\ msantosh.gr@gmail.com
}

(Received : 24/03/2019; Revised accepted : 17/09/2019)

https://doi.org/10.18814/epiiugs/2020/020006

The Southern Granulite Terrane (SGT), the wedgeshaped southern termination of Peninsular India, is a mosaic of several crustal blocks and intervening collisional sutures/shears which developed through multiple orogenic cycles during Mesoarchean to late Neoproterozoic-Cambrian. The SGT has been the focus of global geoscience world for more than four decades mainly with regard to deep crustal processes, crustmantle architecture, polyphase structural evolution, extreme crustal metamorphism, growth and recycling of continental crust, and the assembly-evolution-disruption of supercontinents through time, among other aspects. The earliest felsic crust in the SGT includes the 3.5-Ga granitoids in the Coorg Block, followed by successive maturation stages marked by younger magmatic phases in the various blocks. The zircon $\delta^{18} \mathrm{O}$ values from the Coorg Block also fingerprint the emergence of continental crust above sea level in the early Earth. Multiple arc-magmatic pulses along the margins of the different crustal blocks of the SGT during Neoarchean and Neoproterozoic, together with accreted remnants of ophiolites and other oceanic components, suprasubduction zone complexes, and exhumed high- to ultrahigh-temperature metamorphic orogens suggest subduction-accretion-collision tectonics that constructed the various crustal blocks through time, and incorporated them within Precambrian supercontinent assemblies.

\section{Introduction}

Peninsular India is a mosaic of several Archean cratonic nuclei welded together by Archean-Proterozoic orogenic belts. Among these, the Dharwar Craton marks the southernmost cratonic domain. The term Southern Granulite Terrain (SGT) arises from the recognition that the region south of the Dharwar Craton is dominantly composed of granulite facies rocks, although different nomenclature was adopted to describe this region in different studies (Radhakrishna, 1989), largely because of the poor understanding of the geochronologic and tectonic framework of this region. Earlier studies considered the southernmost part of Peninsular India as a single large mobile belt surrounding the Dharwar Craton (Fig. 1a). Most of the early works

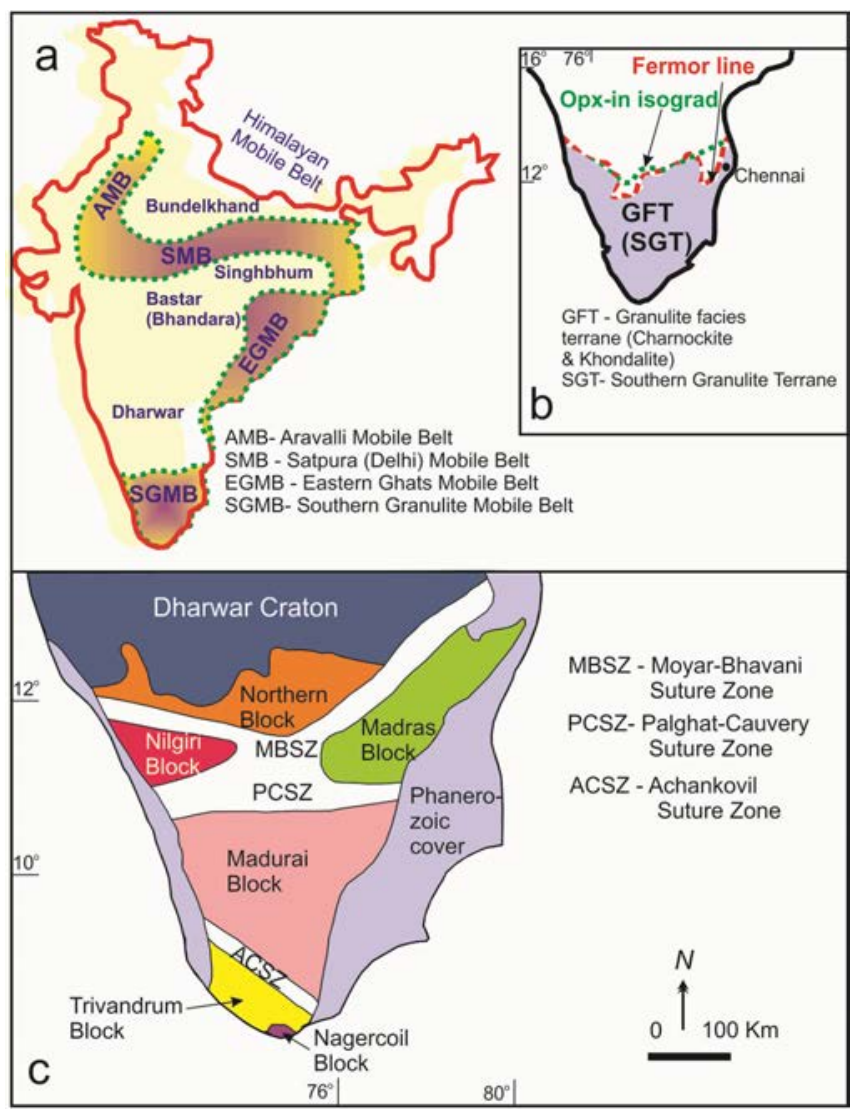

Figure 1. (a) Indian sub-continent showing the major cratons and orogenic belts conceived as mobile belts. Note that the southern part was defined as a single unified mobile belt, termed the Southern Granulite Mobile Belt. (b) The Fermor line and orthopyroxene isograd in southern India, considered to mark the boundary of a single and unified high grade metamorphic terrane to the south. (c) The emergence of the concept that southern India comprises distinct crustal blocks dissected by major shear/suture zones (Harris et al., 1994; Santosh et al., 2003). 
considered the terrane south of the Dharwar Craton as a single entity, with the northern limit marked by the orthopyroxene-in isograd, or the Fermor line (Fig. 1b). Following detailed structural and geological interpretation by S.A. Drury and team based on satellite images (Drury and Holt, 1980), a better picture of the tectonic framework of this region emerged. The pioneering geochronological works of Harris et al. (1994) and Santosh et al. (2003) revealed that the terrane south of the Dharwar Craton is a mosaic of different crustal blocks, dissected by major shear zones, some of which are now recognized as the traces of oceanic sutures (Fig. 1c). The SGT was originally defined as the region south of the Palghat-Cauvery Shear Zone (PCSZ), with the blocks to the north up to the southern margin of the Dharwar Craton termed as the Northern Bock. However, this nomenclature is apparently confusing because many of the blocks in between the Dharwar Craton and the PCSZ are also dominantly of granulite facies. Therefore, in this paper, I prefer the classification in some of our recent papers (e.g., Santosh et al., 2015, 2017) where we define the SGT as the whole region south of the southern margin of the Dharwar Craton (Fig. 2).

The SGT has been the focus of geoscience world for more than four decades mainly with regard to deep crustal processes, crust-mantle interaction, crustal and mantle structure, polyphase structural evolution, extreme crustal metamorphism, growth and recycling of

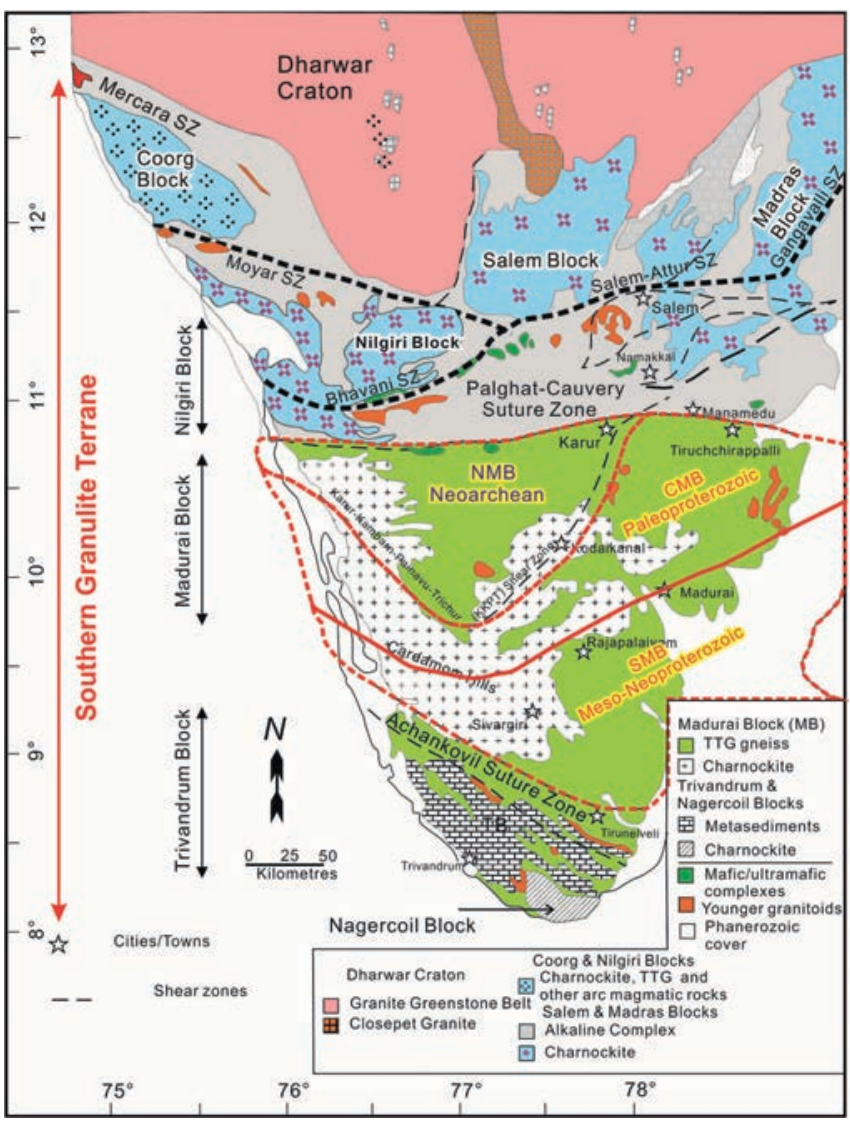

Figure 2. The current concept on the tectonic framework of southern India where the Southern Granulite Terrane is defined as the region south of the Dharwar Craton, comprising various crustal blocks amalgamated along zones of subduction and collision. The Madurai Block at the center is a composite block composed of thee subblocks (Santosh et al., 2017). The Coorg Block in the north is considered as an 'exotic' Mesoarchean block (Santosh et al., 2015). continental crust, and the assembly-evolution-disruption of supercontinents through time, among other aspects. The 1980s witnessed the global debate over granulite petrogenesis, with charnockites, particularly incipient charnockites attracting much attention. Local quarry-scale studies and conventional petrology were the main tool. The 1990s saw a flurry of activity on ultrahightemperature (UHT) metamorphism for which also the SGT offered several good examples. Regional studies and tectonic modeling were initiated during the 2000s including geochronological studies using modern tools. From 2010, integrated petrological, geochemical and geochronological studies and tectonic modeling were given more attention, in accordance with the improvements in analytical tools and advancements in science.

Several hundred papers were published during these years on the various aspects of the SGT leading not only to a better understanding of the geological history of this region, but also in answering some of the fundamental problems related to deep crustal processes, role of fluids in granulite facies metamorphism, early Earth history and plate tectonics, crustal metamorphism at extreme thermal conditions, mantle architecture and crustal structure, and history of supercontinents, among other frontier themes in earth sciences. Thus, SGT ranks as one of the most widely studied geological terranes in the world with several world-class examples of rock types and geological processes.

In this paper I attempt to provide a synoptic view of some of the salient highlights of the characteristics and evolution of the SGT. Due to the voluminous publications and information boom from this region over the last few decades, it is beyond the scope of this short article with limited space allocated in this volume to cover even many of the important studies. This paper therefore does not claim to be a comprehensive review of the SGT, and owes apology to all those valuable contributors whose works are not explicitly mentioned.

\section{Major crustal blocks, intervening tectonic zones and dominant lithology}

The SGT is bordered on the north by the Dharwar Craton and by ocean on the other three sides, forming the wedge-shaped termination of the Indian Peninsula. The major crustal blocks in the SGT include the Coorg, Salem, BR Hills, Nilgiri, Madras, Madurai, Trivandrum, and Nagercoil (Fig. 2). The Coorg Block is welded to the Dharwar Craton along the Mercara suture, and to the south with Nilgiri Block along the Moyar suture. The Madras block is bordered on the west by the Nallamalai suture. The major shear zone system of PalghatCauvery, another paleo-suture, marks the southern boundary of the northern crustal blocks in SGT. The Madurai and Trivandrum Blocks to the south are separated by the Achankovil zone. The Nagercoil Block at the tip of the Peninsula is a fragmental crustal block, the counterpart of which might be located somewhere in East Africa. A charnockite island off the coast of Kanya Kumari at the southern tip of India, where the famous Vivekananda Statue is erected, has been termed as the "Gondwana junction" referring to the connection among the erstwhile eastern Gondwana fragments (Santosh, 1996).

Charnockite (orthopyroxene-bearing anhydrous granulite), the type area of which is located in the Pallavaram Hills of the Madras Block, is the dominant rock type in most of the crustal blocks of the SGT (except in the Trivandrum Block), occurring as massive mappable units including in the Coorg, Nilgiri, Salem, Madras, B.R. Hills, 
Madurai, and Nagercoil Blocks (Clark et al., 2009; Samuel et al., 2014; Santosh et al., 2003a; 2015; 2017) and covering large areas of the higher topography of the Western Ghats mountain belt. The next major rock type is TTG (tonalite-trondhjemite-granodiorite) gneisses and their migmatized variants, forming the basement rock in some of the older crustal blocks. Intrusive granitoids of both Archean and Proterozoic ages occur in some of the blocks, constituting an integral part of the vertical continental crust building process (Santosh et al., 2009; 2015). Supracrustal rocks including metasediments of different metamorphic facies occur adjacent to the margins of many of the crustal block as accreted units, reflecting lateral growth of continent. The largest of these occurs within the Trivandrum Block, also termed as the Kerala Khondalite Belt (Chacko et al., 1987), where garnetsillimanite-cordierite-spinel and graphite bearing aluminous sediments metamorphosed to granulite- and ultra-high temperature granulite facies occur widely, intercalated with garnet and biotite bearing felsic gneisses (termed as leptynites). The suture zones and their flanks are dominated by amphibolites or their higher grade equivalents, mafic and ultramafic units, and banded iron formations. Rare dismembered ophiolite slivers including ultramafic-gabbro-plagiogranite/ trondhjemite association occur in some localities, such as the Neoarchean sequence in Agali along the margin of the Nilgiri Block and the Neoproterozoic sequence in Manamedu along the southern margin of the PCSZ (Santosh et al., 2012, 2013). However, ophiolite suites are relatively rare in the Precambrian high grade terrane of SGT, probably because these were already removed by prolonged and deep erosion. Gabbro-anorthosite in association with cumulate pyroxenite representing supra-subduction zone complexes occur in some localities, such as in Sittampundi (Ram Mohan et al., 2013). Within the PCSZ, around Salem town, large exposures of ultramafic rocks occur, possibly representing sub-continental lithospheric mantle sections, or magmas derived from the mantle, with extensive alteration to magnesite.

Among the rock types in the SGT that have attracted global attention are the incipient charnockites and $\mathrm{Mg}-\mathrm{Al}$ rich ultrahightemperature (UHT) granulites. The incipient charnockites are patches, veins, lenses or ladders of greenish domains carrying orthopyroxenebearing granulite facies assemblages overprinting the host gneisses, which are either TTG-type basement rocks with magmatic protoliths, or garnet- and biotite-bearing metasediments. These rocks which occur on a mesoscopic scale are sometimes referred to as 'arrested charnockites' and have been central to the debate over the mechanism of granulite formation (Srikantappa et al., 1985; Hansen et al., 1987; Santosh et al., 1990). (See later section for detailed discussion on the role of fluids in incipient charnockite formation). The SGT also hosts some of the world's classic UHT granulites with diagnostic mineral assemblages which suggest extreme crustal metamorphism under ultrahigh temperature conditions (Tsunogae and Santosh,2010). These will be discussed in a later section in this paper.

Another important rock suite in the SGT comprises a range of sub-alkaline to alkaline intrusions of granites and syenites distributed within the various crustal blocks and intervening zones, puncturing the basement rocks at several localities. Although volumetrically minor, these intrusions which range in age from mid-Neoproterozoic to Cambrian are tectonically important indicators of the widespread "Pan-African" felsic and alkaline magmatic event in the Gondwana fragments (Santosh and Drury, 1988). Geochemically, these rocks show tectonic affinity ranging from volcanic-arc to within-plate setting, and mark the trail of a changing tectonic regime from subduction to collision and post-collision, evidently associated with the history of assembly of Gondwana.

Representative examples of the geology and distribution of lithologies in one crustal block (Coorg Block) and along a suture zone and its flanks (Nallamalai suture) are shown in Fig. 3. Field photographs of some of the representative rock types are shown in Fig. 4.

\section{a) Geological map of Coorg Block and surrounding regions}

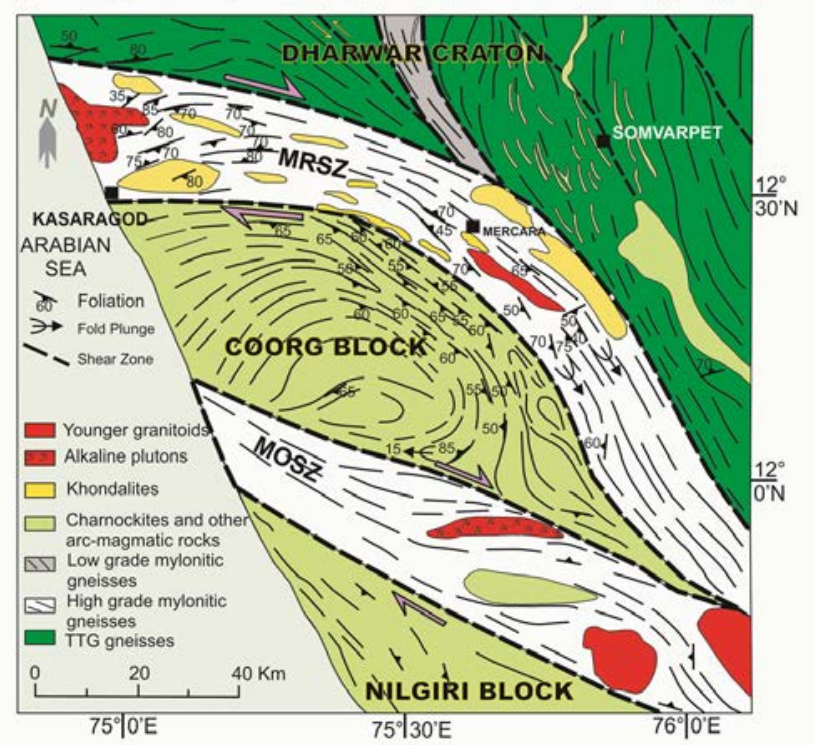

b) Geological map of Nallmalai suture and surrounding regions

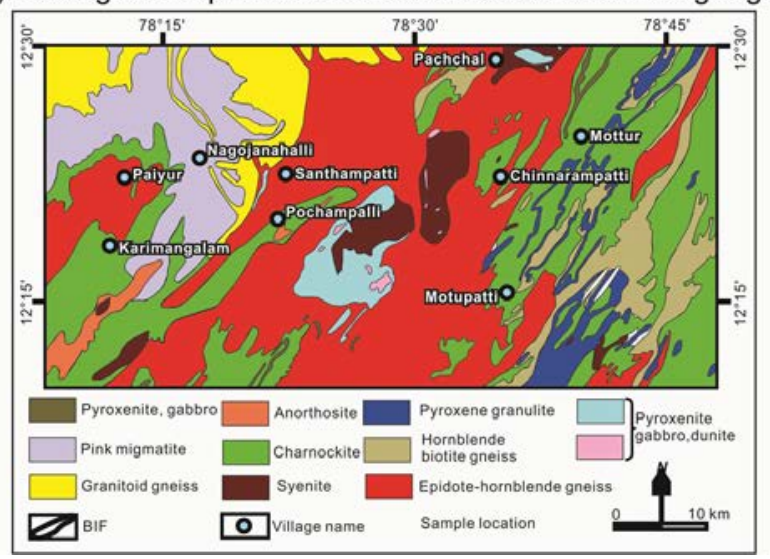

Figure 3. Representative geological maps of crustal block and suture zone region. (a) Coorg Block (Santosh et al., 2015). The Nallamalai suture zone and surrounding regions (Li et al., 2018).

\section{Salient geochemical features}

Extensive major, trace and rare earth element geochemical data were published in various works on the different rock types from various crustal blocks and intervening tectonic zones in the SGT. Rajesh and Santosh (2004) summarized the geological features of Archean and Proterozoic massive charnockites from thee SGT, classifying these as both felsic and intermediate types. The intermediate charnockites show analogy with high-Ba-Sr granitoids with low $\mathrm{K}_{2} \mathrm{O} / \mathrm{Na}_{2} \mathrm{O}$ ratios, whereas the felsic types display higher $\mathrm{K}_{2} \mathrm{O} / \mathrm{Na}_{2} \mathrm{O}$ ratios. Charnockites from most of the blocks show arcrelated signature with formation within convergent margin setting. 

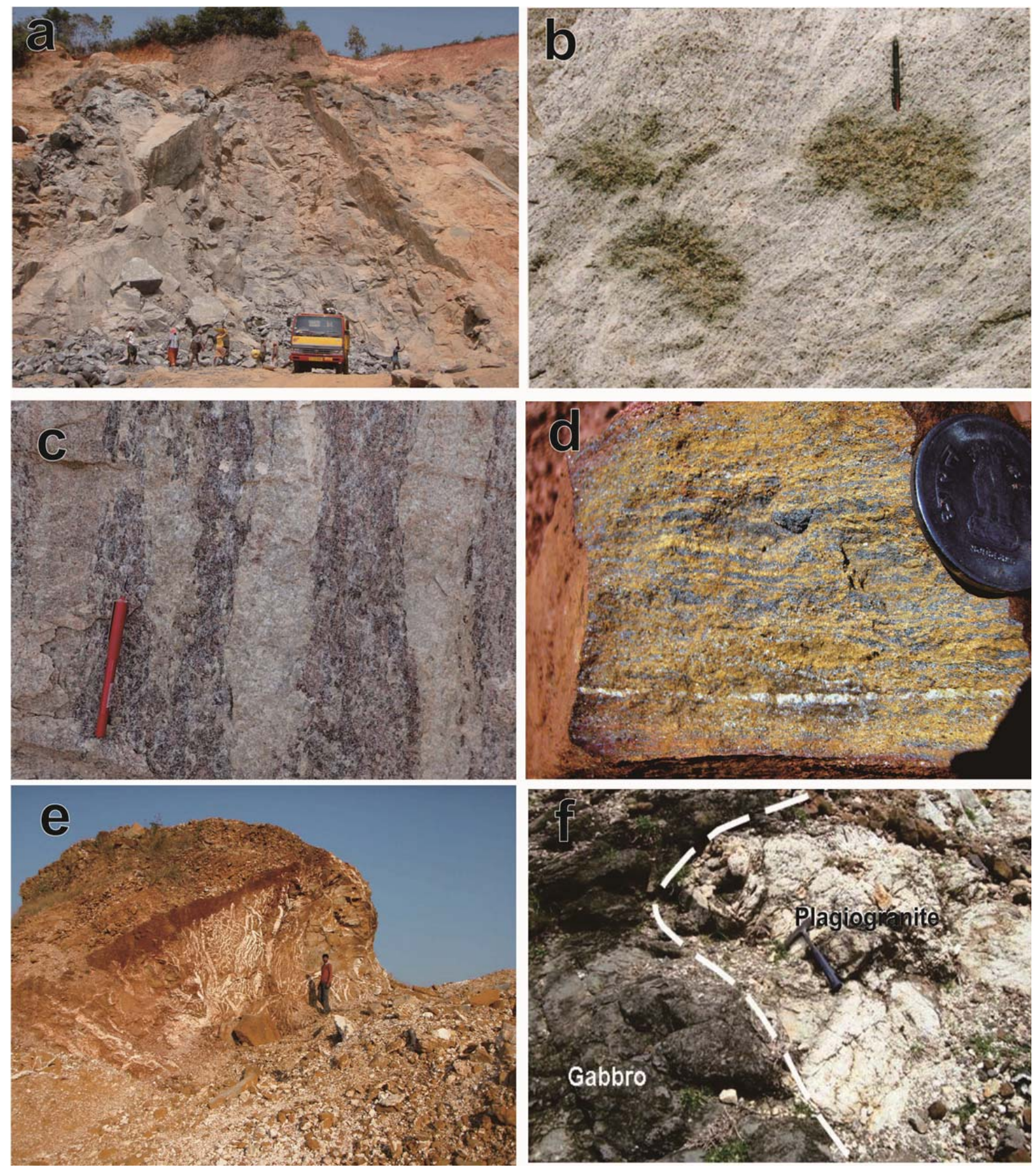

Figure 4. Representative filed photographs of some of the important rock types in the Southern Granulite Terrane. (a) Massive charnockite from the Coorg Block. (b) Incipient charnockites occurring as patches within garnet and biotite bearing felsic gneisses at Kottavattom. (b) Garnet-sillimanite-cordierite-spinel-bearing ultrahigh temperature granulite facies metapelites (khondalites) in the Trivandrum Block. (d) Sulphidic banded iron formations from the Wyand region, west of the Nilgiri Block. (e) Sub-continental lithosphere mantle section in Salem where ultramafic rocks show extensive carbonic metasomatism and formation of veins and accumulations of magnesite. (f) The gabbro-plagiogranite association in the ophiolites of Manamedu within the southern part of the Palghat-Cauvery Suture zone.

For example, the geochemical features of Neoarchean charnockites and associated magmatic suites from the Madurai Block are characterized by distinct Nb, Ta, and Ti depletion and enrichment in light rare earth element suggesting magmatism in a subduction-related environment (Santosh et al., 2017). The Mesoarchean magmatic suite from the Coorg Block also displays arc-related signature and convergent margin origin (Fig. 5; Santosh et al., 2015).
The charnockites from Nilgiri Block are mostly magnesian and calcic to calc-alkaline, with relatively low $\mathrm{K}_{2} \mathrm{O}$, and $\mathrm{Zr} / \mathrm{Ti}$, and the trace element ratios like (La/Yb)n/(Sr/Y), (Y/Nb), (Y + Nb)/Rb, (Y + $\mathrm{Ta} / \mathrm{Rb}, \mathrm{Yb} / \mathrm{Ta}$ indicate a volcanic arc signature consistent with arc magmatism associated with oceanic plate subduction (Samuel et al., 2014).

The primitive mantle normalized trace element patterns of the 

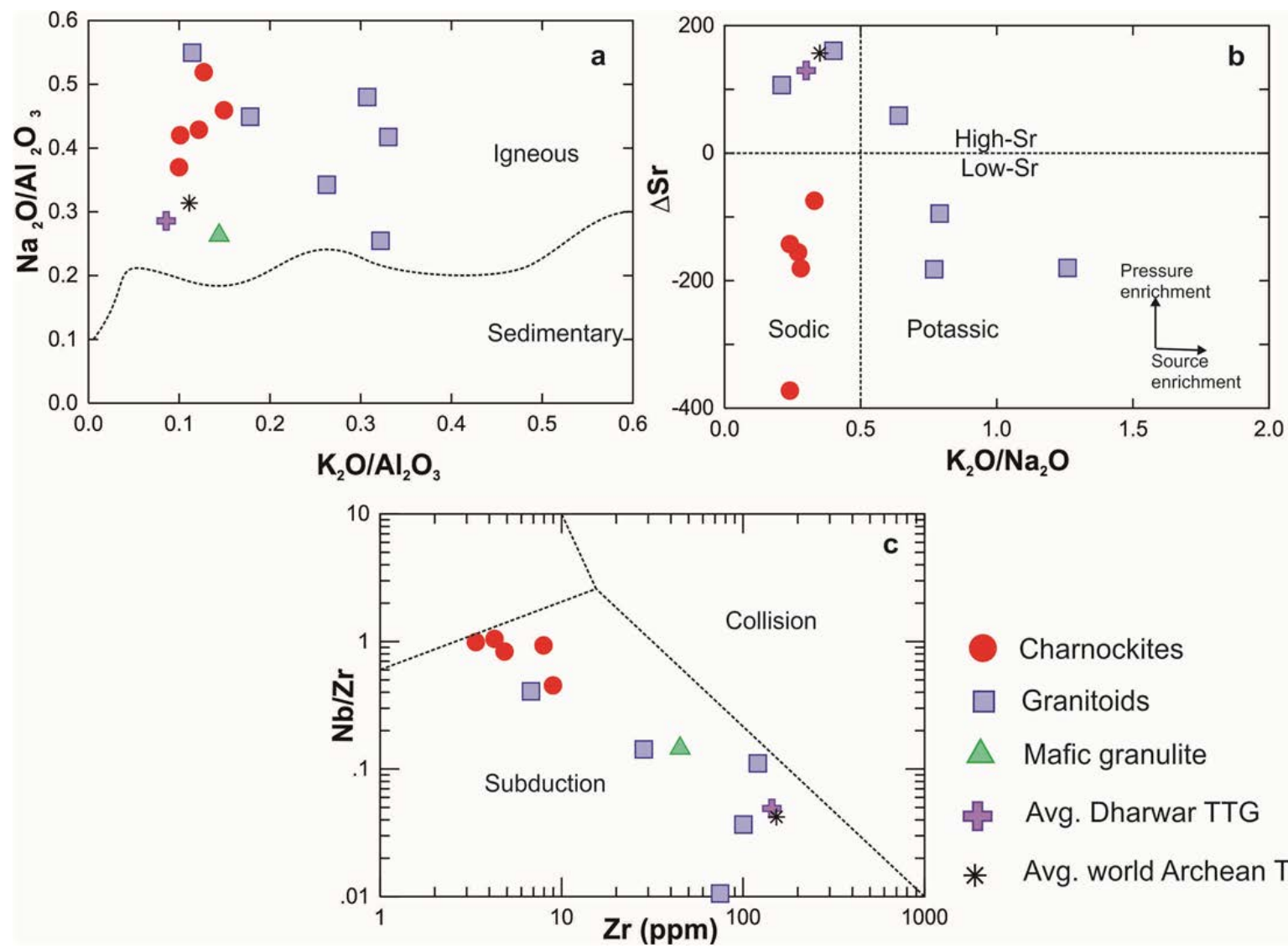

Charnockites

Granitoids

Mafic granulite

Avg. Dharwar TTG

Avg. world Archean TTG

Figure 5. Representative geochemical plots of arc magmatic assemblages from the Coorg Block, with magma generation in subductionrelated setting (after Santosh et al., 2015).

charnockites and TTG rocks from this block show enrichment in large ion lithophile elements (LILE) and comparable high field strength elements (HFSE), consistent with subduction-related origin.

Shaji et al. (2014) reported the geochemical features of a suite of amphibolites, metagabbros, and TTG gneisses from the Nilambur region along the western flanks of the Nilgiri Block which they correlated to a common basaltic protolith. Their data indicate formation of these rock in primitive arc magmatic settings with MORB-like components in the source followed by magmatic differentiation. The amphibolites and metagabbros are characterized by negative $\mathrm{Nb}-\mathrm{Ta}, \mathrm{Zr}-\mathrm{Hf}$ and $\mathrm{Ti}$ anomalies, typical of subductionrelated intraoceanic tholeiitic arc basalt. The rocks also display marked enrichment in LILE and LREE, with depletion of HFSE. A nearly flat to slightly enriched LREE enriched pattern, with $\mathrm{P}, \mathrm{Ti}$, Th and $\mathrm{Nb}$ depletion is also noted. The authors correlated these results with magma generation in subduction-related settings.

The geochemical features of suprasubduction zone complexes in the SGT including the ophiolite suites and gabbro-anorthosite complexes also indicate active convergent margin settings and subduction-related processes (Santosh et al., 2012; Ram Mohan et al., 2013).

The lithological sequences within suture zones are also products of subduction accretion and collision processes. Li et al. (2018) suggested tholeiitic to calc-alkaline parental melts for the maficintermediate-felsic suite of rocks within the Nallamalai suture zone, generated by low degree partial melting of a peridotitic mantle wedge metasomatized by subduction-derived fluids and sediments. They suggested continuous slab melting ensued by intracrustal fractional crystallization of melts with reworking of older continental crust. The BIF samples from this zone display positive Eu anomalies, negative to negligible Ce anomalies, and superchondritic Y/Ho ratios suggesting their formation in an oceanic realm proximal to an active continental margin setting.

\section{Geochronology and crustal evolution}

Although conventional Rb-Sr, Nd, K-Ar and other age data were published in the early years from several rock types in the SGT, terranescale isotopic geochronological studies started with the input of Paul Taylor at Oxford, leading to the milestone publication by Harris et al. (1994) on the on Nd-isotope analyses from a range of lithologies, including from the SGT. The charnockites, metasediments, and granitoids from the SGT defined contrasting age provinces and paved way for the new models on the assembly of crustal blocks. The region north of the PCSZ and the granulite blocks of Nilgiri and Madras yielded model Nd ages from 3.4 to $2.4 \mathrm{Ga}$ signifying crustal growth during the Late Archean. In contrast, late Neoproterozoic-Cambrian high grade metamorphism resulted in $\mathrm{Sm} / \mathrm{Nd}$ fractionation in the rocks south of the PCSZ. Model Nd ages computed for Sm/Nd fractionation at 550 Ma show a range of 2.9 to $1.3 \mathrm{Ga}$. This range compares closely with published model $\mathrm{Nd}$ ages from the high-grade terrain of Sri Lanka. Harris et al. (1994) provided the fundamental basis to mark the PCSZ as a major terrane boundary. This was complimented by another study by Bartlett et al. (1998) on single zircon U-Pb dating 
which further revealed Neoproterozoic protolith ages within the Achankovil Shear Zone region that demarcates the boundary between Madurai Block and Trivandrum Block in the southern part of the SGT. The next comprehensive geochronological study involved a N$\mathrm{S}$ traverse across the SGT covering several crustal blocks and intervening suture zones, and although the technique involved EPMA CHIME dating of zircon and monazite grains, the comprehensive data revealed the Archean through Paleoproterozoic to latest Neoproterozoic-Cambrian tectonothermal history of the SGT (Santosh et al., 2003b). Comprehensive Nd isotopic data were also reported by other workers which provided important clues to terrane boundaries (Bhaskar Rao et al., 2003).

Subsequently several isotopic geochronological studies were published from different parts of the SGT mostly focusing on specific problems of dating magmatic or metamorphic events, and some works pertaining to regional crustal evolution models. In the recent y ears, zircon $\mathrm{U}-\mathrm{Pb}$ geochronology was coupled with $\mathrm{Lu}-\mathrm{Hf}$ isotopes, thus providing a better understanding of not only the thermal regimes but also the source characteristics and leading to regional crustal evolution models for the SGT. A few studies from the different blocks are mentioned below and shown in Fig. 6.

The oldest crustal block in the SGT is the Coorg Block from where Santosh et al. (2015) reported zircon U-Pb geochronology and $\mathrm{Lu}-\mathrm{Hf}$ isotopes of all the major lithologies.They obtained weighted mean ${ }^{207} \mathrm{~Pb} /{ }^{206} \mathrm{~Pb}$ ages of 3153 to $3184 \mathrm{Ma}$ for syenogranites, 3170 Ma for biotite granite, 3275 Ma for trondhjemite, 3133 to 3163 for charnockites,3156 to 3158 for mafic enclaves, 3161 Ma for diorite and 3173 Ma for felsic volcanic tuff. The results presented in this study indicate prominent Mesoarchean magmatism and crust building during 3.3 to $3.1 \mathrm{Ga}$ followed by metamorphism at ca. 3.0 to $2.9 \mathrm{Ga}$. The majority of zircon grains from these rocks display Hf isotope features typical of crystallization from magmas derived from juvenile sources. The Hf crustal model ages suggest that the crust building might have also involved partial recycling of basement rocks as old as ca. 3.8 Ga. The SGT preserves imprints of major tectonothermal events at $2.5 \mathrm{Ga}, 2.0 \mathrm{Ga}, 0.8 \mathrm{Ga}$ and $0.55 \mathrm{Ga}$ associated with various subduction-accretion- collision or rifting events. In contrast, the Coorg Block remained unaffected by the younger events (Fig. 6a,c). The 3.5-Ga granodiorite from the Coorg block (Roberts and Santosh, 2017) records the earliest felsic crust in the SGT. Younger phases of magmatism at 3.37-3.27 and 3.19-3.14 Ga, comprising both reworked crust and juvenile components are considered to represent successive crustal maturation. The zircon d180 values through time indicate an increase in both the amount of sediment recycling and hence, crustal thickening, as well as an increase in the emerged area of continental crust available for weathering (Roberts and Santosh, 2017).

Neoarchean crust building is widely recorded from various blocks to the north of the PCSZ including Nilgiri, Salem, BR Hills and the Nallamali Suture Zone and surrounding regions of the Madras Block (Clark et al., 2009; Samuel et al. 2014, Ratheesh-Kumar et al., 2016, Li et al., 2018). However, detailed studies on the Madurai Block revealed that it is a composite block composed of a northern Archean-Paleoproterozoic segment, a central Paleoproterozoic domain and a southern Neoproterozoic domain (Plavsa et al., 2014). Another recent study (Santosh et al., 2017) on a suite of magmatic rocks from the southern margin of the Madurai Block confirmed Neoproterozoic juvenile crustal growth in this region. Zircon grains yielded weighted mean ${ }^{206} \mathrm{~Pb} /{ }^{238} \mathrm{U}$ ages of 786 to $772 \mathrm{Ma}$ in alkali granites, 938 to $786 \mathrm{Ma}$ in charnockites, and $926692 \mathrm{Ma}$ in enderbites suggesting continuous and multiple pulses of magmas emplaced throughout early to midNeoproterozoic. Metamorphic zircon grains from all the rock types show latest Neoproterozoic-Cambrian ages in the range of 567 to $510 \mathrm{Ma}$. Zircon Lu-Hf data show that the alkali granite-charnockite-enderbite suite has depleted mantle ages (TDM) in the range of 1164-2172 Ma and

Fig. 6 (a) and (b) Multiple crust building events in the Southern Granulite Terrane during EoarcheanMesoarchean and Neoproterozoic shown through zircon $U$-Pb data from two representative $c$ rustal blocks. Extensive crust building and recycling also occurred during Neoarchean and Paleoproterozoic in some crustal blocks. (c) Zircon Hf data from the Coorg Block showing juvenile crust building from depleted mantle sources during Mesoarchean, as well as reworking of older Eoarchean crust. (Santosh et al., 2015, 2017). 
crustal residence ages (TDM C ) of 1227-3023 Ma. Both negative and positive $\varepsilon H f(t)$ values (-22.1 to 10.6), suggest magma derivation from mixed juvenile mid- to late-Mesoproterozoic components and reworked Mesoarchean to mid-Mesoproterozoic components. Zircon from the gabbroic rocks yielded depleted mantle ages and (TDM) in the range of 1112-2046 Ma, crustal residence ages (TDM C) of 1306$2816 \mathrm{Ma}$, and both negative and positive $\varepsilon \mathrm{Hf}(\mathrm{t})$ values (-17.8 to 7.9), indication from juvenile mid-Mesoproterozoic to Neoproterozoic components as well as reworked Mesoarchean to midMesoproterozoic sources. The data were interpreted to suggest multiple arc magmatism along the southern Madurai Block during distinct pulses throughout early to late Neoproterozoic, and an active convergent margin along this zone at this time, culminating in collisional metamorphism during latest Neoproterozoic-Cambrian associated with Gondwana assembly (Fig. 6b)

The dominant Neoproterozoic-Cambrian ages in metasediments from the Trivandrum Block were previously interpreted to indicate Neoproterozoic deposition followed by Cambrian metamorphism (Collins et al., 2007a). However, this was challenged by Kroner et al. (2015) based on zircon SHRIMP dating of magmatic zircons from granitoid gneisses and charnockites of the Trivandrum and Nagercoil Blocks from where they reported protolith emplacement ages between 1765 and ca. 2100 Ma and also variable recrystallization and/or leadloss during the late Neoproterozoic-Cambrian at around 540 Ma. Zircon $\mathrm{Hf}$ and whole rock Nd isotopic data suggest that the protoliths were derived from mixed crustal sources, and $\mathrm{Hf}-\mathrm{Nd}$ model ages vary between 2.2 and 2.8 Ga. Kroner et al. (2015) thus considered that the Trivandrum and Nagercoil Blocks as a single tectonometamorphic terrane predominantly consisting of Paleoproterozoic granitoids interlayered with supracrustal rocks that are older than ca. 2100 Ma.

There is clear evidence for Neoproterozoic oceanic subduction culminating in Cambrian collisional metamorphism along the margins of the some of the crustal blocks. Thus, the Manamedu ophiolite suite along the boundary between the northern part of the Madurai Block and the southern margin of the PCSZ marks the trace of an oceanic suture (Santosh et al., 2012). Secondary Ion Mass Spectrometry (SIMS) U-Pb ages from zircons in plagiogranites and gabbros from this suite show $206 \mathrm{~Pb} / 238 \mathrm{U}$ ages of $737 \mathrm{Ma}$ and $782 \mathrm{Ma}$ corresponding to the timing of emplacement of these rocks. The plagiogranite also contains metamorphic zircons with age of $513 \mathrm{Ma}$. The magmatic zircon ages from Manamedu also compare with those from the felsic volcanic suite of the Kadavur gabbro-anorthosite complex to the south of Manamedu, all suggesting a mid-Cryogenian subduction system along the southern periphery of the PCSZ prior to the final collision associated with the amalgamation of the Gondwana supercontinent. In summary, the northernmost part of the SGT preserves some of the oldest crust in Peninsular India with prominent Mesoarchean imprint. Towards the central part, the basement is mostly Neoarchean and Paleoproterozoic. Further south, Paleoproterozoic rock dominate. Major crust building events occurred during Mesoarchean, Neoarchean and Paleoproterozoic, with minor juvenile additions and extensive reworking in the Neoproterozoic. Part of the older crust was also reworked during the Neoarchean- Paleoproterozoic events.

\section{Ultrahigh-temperature metamorphism}

Crustal metamorphism at extreme thermal conditions termed as ultrahigh-temperature (UHT) metamorphism generates diagnostic mineral assemblages depending on the protolith composition. The Madurai Block came into focus with regard to UHT metamorphism (e.g., Raith et al., 1997; Sajeev et al., 2004), including a landmark discovery by Tateishi et al. (2004) of sapphirine+quartz in equilibrium, marking one of the diagnostic assemblages of extreme thermal conditions. Following this, several new reports appeared from various localities in the PCSZ and surrounding areas on UHT mineral assemblages including rare corundum-bearing UHT rocks (Shimpo et al., 2006). Sapphirine + quartz, thought to be a rare association, was subsequently identified from various localities (Tsunogae and Santosh, 2010, and references therein) (Fig. 7). Further studies also revealed that the UHT metamorphism is widespread in the various crustal blocks of the SGT south of the PCZ including the Trivandrum and Nagercoil Blocks, and the UHT event is dated as late Neoproterozoic-Cambrian (Santosh et al., 2006; Johnson et al., 2015), clearly correlating with the timing of final assembly of the Gondwana supercontinent.

Many studies in the SGT have attempted to define metamorphic pressure-temperature time (P-T-t) paths, mainly from the high- and ultrahigh-temperature assemblages. These have resulted in contrasting interpretations ranging from simple isothermal decompression (ITD) or isobaric cooling (IBC) trajectories to more complex hairpin-like prograde-peak-retrograde paths. Tsunogae and Santosh (2010) evaluated the P-T paths of UHT granulites, particularly those carrying the diagnostic sapphirine + quartz assemblage in equilibrium from various localities of the SGT. They identified that in some localities, isobaric cooling from sapphirine + quartz to orthopyroxene + sillimanite + quartz fields, occurred along a counterclockwise P-T path. In contrast, sapphirine + quartz occurring as coronas around Mg-rich staurolite within poikiloblastic garnet suggests decompression along a clockwise P-T trajectory. The contrasting P-T paths might correlate with the different styles of tectonics that contribute to heat input and subsequent exhumation, such as from underplated mafic magmas through mantle upwelling, or subductionrelated processes including slab-window from ridge subduction, or slab-breakoff following collision.

\section{Role of fluids}

The SGT has been central to the debate on the role of fluids in granulite metamorphism and has attracted geoscientists from various parts of the world to work with their Indian counterparts, leading to several landmark papers carrying innovative ideas and building our knowledge base on fluid-rock interaction in the deep crust and crustmantle exchange.

The 'wave' of research on fluids in the deep crust started with focus on incipient charnockites - the coarse greasy green patches, veins and lenses developed over leucocratic felsic gneisses as described from several quarry sections, particularly from the Trivandrum Block, and its counterparts in adjacent terranes (Srikantappa et al.,1995; Hansen et al., 1997; Santosh et al., 2010). The conversion of the gneisses to incipient charnockites is thought to have been controlled by the influx of $\mathrm{CO}_{2}$ rich fluids which buffered the water activity to low levels thereby generating the anhydrous charnockitic assemblage. Fluid inclusion studies found new dimensions in answering some of the potential questions related to the nature, composition and role of fluids in granulite metamorphism. Combined with mineral phase equilibria, these studies offered a powerful technique to constrain the P-T-X conditions. In order to 

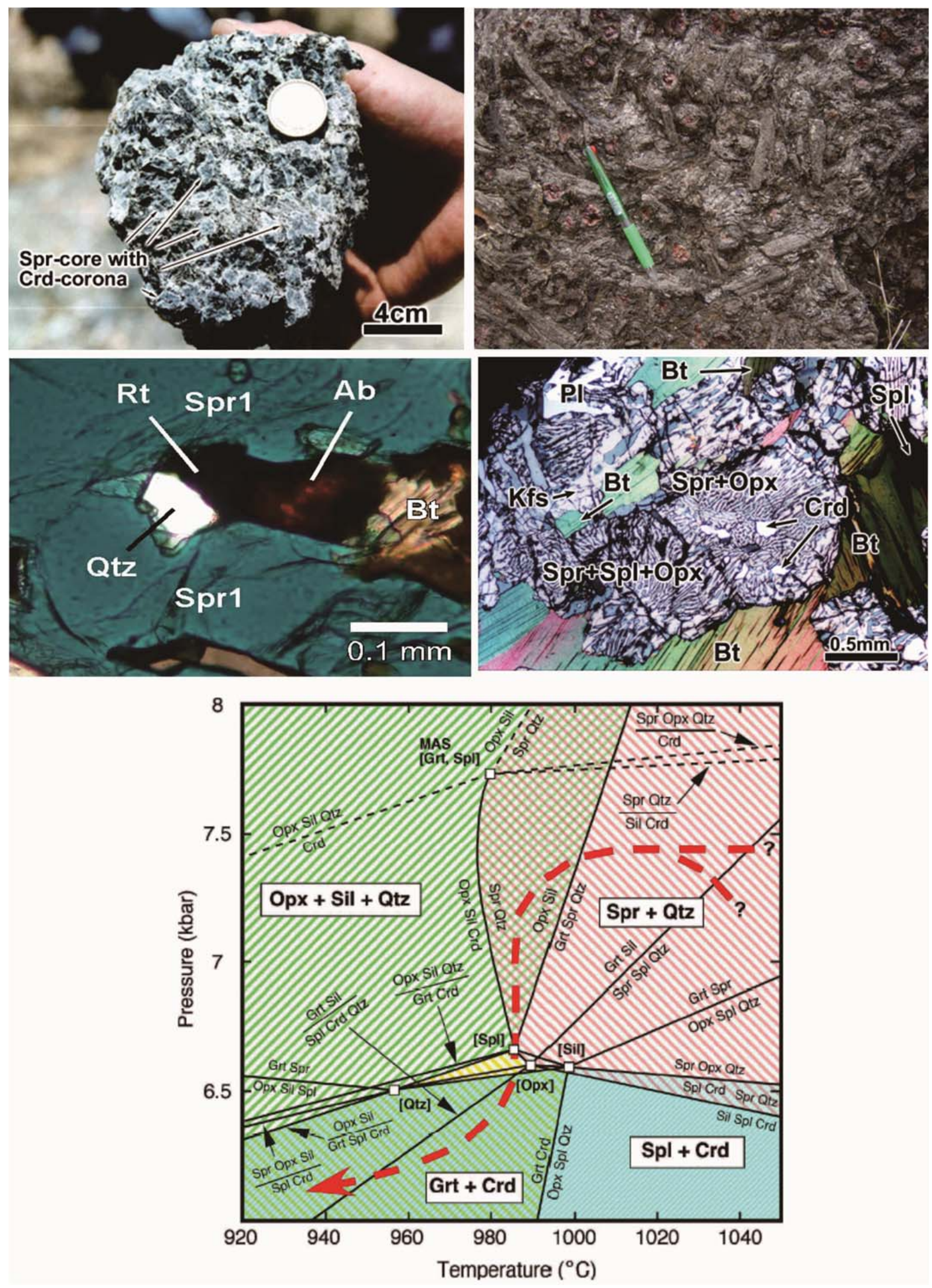

Figure 7. Top two panels on left and right are hand specimen and field photographs of ultrahigh-temperature sapphirine-bearing granulites from the Palghat-Cauvery SutureZone area. Middle two panes are representative photomicrographs of ultrahigh temperature granulite facies mineral assemblages with left one showing the rare sapphirine + quartz assemblage and the right one showing symplectitic intergrowths of sapphirine, orthopyroxene, cordierite and spinel. The bottom figure shows a representative P-T plot with P-T path of ultrahigh-temperature metamorphism in the Southern Granulite Terrane (after Tsunogae and Santosh, 2010, and references therein). Mineral abbreviations: Sprsapphirine; Qt- quartz; Bt-biotite; Spl-spinel; Opx orthopyroxene; Crd-cordierite; Pl-plagioclase; Kfs- K-feldspar; Rt-rutile. 
address the debate on the origin of fluids, carbon stable isotope studies were employed on fluid inclusions in samples from gneiss-charnockite reaction fronts (Fig. 8a; Santosh et al., 1990) and coupled with microthermometric data, these results provided important insights on $\mathrm{CO}_{2}$ advection along structural pathways that contributed to the formation of the incipient charnockite assemblage. Debates surrounded the origin of fluids including the decarbonation of carbonate rocks (Harley and Santosh, 1995; Satish-Kumar et al., 2002), although the results all pointed to sub-lithospheric magmatic sources for the carbonic fluids.

The infiltration of $\mathrm{CO}_{2}$-rich fluids into country rocks which were under reducing conditions (due to the presence of disseminated graphite in these rocks) resulted in the precipitation of coarse flakes of graphite in veins, pegmatites and mesoscopic shear zones. The different types of graphite associations in the Trivandrum Block were investigated using micro-analytical techniques of carbon isotopes leading to insightful models on fluid propagation through the earth's crust (Santosh and Wada, 1993a,b; Fig. 8b).

The SGT remains as a rare example where multiple approaches converged to indicate $\mathrm{CO}_{2}$ influx from sub-lithospheric sources as an important process that assisted in the formation of anhydrous granulite facies assemblages in the lower crust, thus enhancing our understanding of crust-mantle interaction processes.

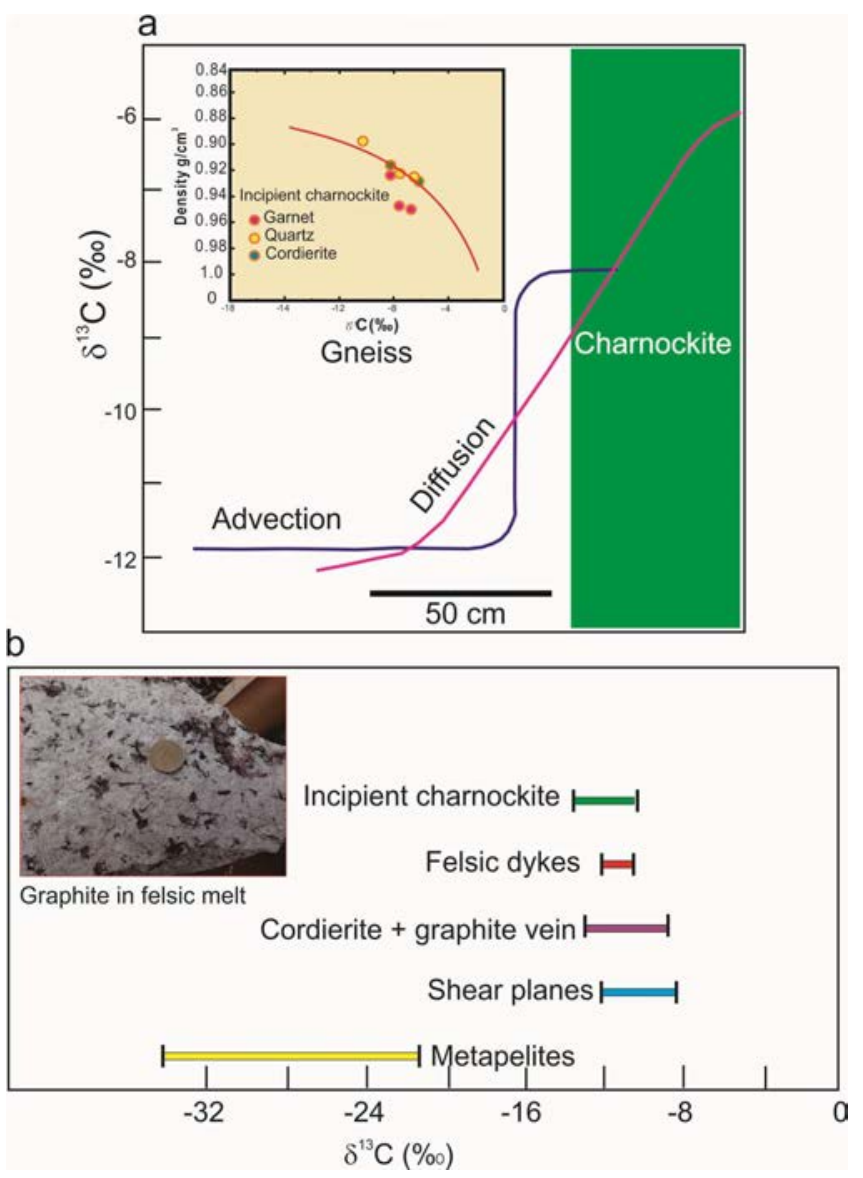

Figure 8. Fluid inclusion and carbon isotope profile across a representative gneiss-incipient charnockite front at Mannantala, Trivandrum Block (after Santosh et al., 1990). The data suggest $\mathrm{CO}_{2}$ advection along structural pathways. (b) Carton isotope data on graphites in various associations from the Trivandrum Block. The inset shows field photograph of coarse graphite flakes in meltrich portions of felsic gneisses within the Trivandrum Block.

\section{Rift-related mafic magmatism}

The various crustal blocks and intervening suture/shear zones in the SGT also preserve evidence for rift-related magmatic activity of various ages. The prominent among these are mafic dykes, representing mantle magmatism associated with incipient rifts. Radhakrishna and Joseph (1996) summarized the results from palaeomagnetic investigations on four major dyke swarms and in conjunction with other available data, they reconstructed the apparent polar wander curve for the Indian Peninsula during Proterozoic. The results show that the Indian landmass was located at mid-latitudes of the Northern Hemisphere during ca. $2000 \mathrm{Ma}$, and at a low latitude near the Equator $\left(\sim 10^{\circ} \mathrm{N}\right)$ during ca. $1800-1750$ Ma. The continent moved close to the South Pole region (60 6 ) by ca. $1650 \mathrm{Ma}$, returning to near the Equator ca. $1000 \mathrm{Ma}$, moving to near the North Pole $\left(80^{\circ} \mathrm{N}\right)$ region at ca. $850-800 \mathrm{Ma}$, and further to $10-30^{\circ} \mathrm{N}$ by 750 Ma. Evidence for plume-related rifting and mafic magmatism are comes from the Cretaceous mafic magmatic suites. Mafic dykes related to the Cretaceous Deccan trap activity are widely identified from the SGT. In a recent study, Shaji et al. (2009) reported the imprints of rift-related Santonian magmatism from alkali gabbro in the Madurai Block of central SGT. The zircon U-Pb mean age of ca. $85 \mathrm{Ma}$ from this rock, together with geochemical features, represent rift-related late Cretaceous magmatism induced by the Marion plume. The mafic magmatic event is correlated with the final phase of India-Madagascar rifting.

\section{Structural models}

Numerous structural investigations were carried out on local and regional domains of the SGT by various workers, which all indicate polyphase deformational history. Among these, the observation of duplex structures and tectonic mélanges with detailed structural cross sections revealing transpressional tectonics along the Cauvery Suture Zone confirm the subduction-accretion history that amalgamated the adjoining crustal blocks (Chetty and Santosh, 2013). A close spatial and temporal relationship was also invoked between transpressive deformation, deep crustal melting, ascent of granite magmas and migmatisation associated with convergent tectonics and extrusion. The crustal architecture of the Cauvery Suture Zone has been visualized as a crustal-scale positive 'flower structure', typical of transpressional tectonics analogous to those along convergent margins (Chetty et al., 2016) (Fig. 9).

Rajesh and Chetty (2006) presented structural fabrics and deformational history of Achankovil Suture Zone dividing the Madurai and Trivandrum Blocks where they found that the initial dextral kinematic movements were superposed and overprinted by subsequent sinistral deformation.

\section{Plate tectonic models and supercontinent connection}

Although many earlier works recognized the role of plate tectonics associated with the magmatic and metamorphic processes in the SGT, the integrated model proposing a Pacific-type orogeny involving oceanic plate convergence, subduction and accretion, arc magmatism and high grade metamorphism (Santosh et al., 2009) could explain many of the features in the crustal blocks and intervening sutures. 
a) Manamedu ophiolite

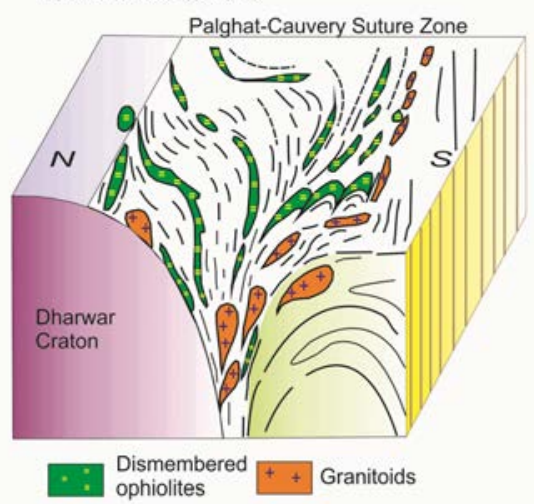

b) Structural cross-section along the central part of the Cauvery Suture Zone showing crustal flower structure

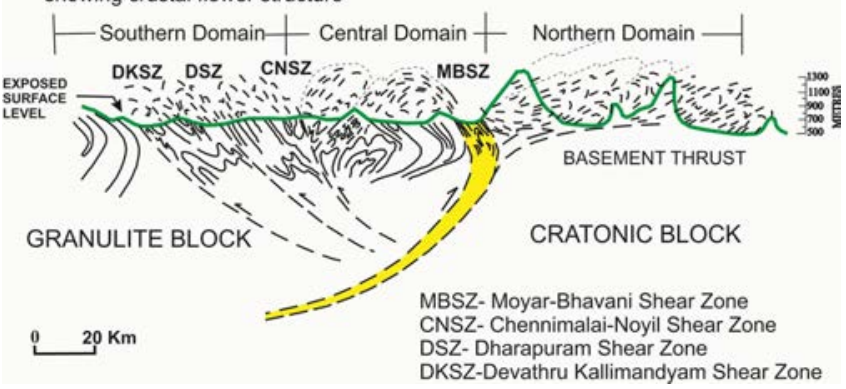

Figure 9. (a) Cartoon structural interpretation of the Cauvery Suture Zone, where 'flower style' exhumation is envisaged (Chetty et al., 2016). (b) Structural cross section across three domains at the margin of the northern cratonic block (Dharwar Craton) and the southern granulite facies block (Southern Granulite Terrane) (Chetty and Santosh, 2013).
The Archean tectonic regime is envisaged to have involved accretion of oceanic arcs and micro continents onto the margin of the Dharwar Craton (Santosh et al., 2013) marking an important event of continental growth, and broadly coinciding with the global crustal growth event at this time (Fig. 10). Slab melting and vertical addition was also fundamental to continental growth in the SGT (Ratheesh Kumar et al., 2016).

The southern margin of the PCSZ is considered to have been an active convergent margin during mid-Neoproterozoic with southward subduction of the Mozambique Ocean lithosphere (e.g., Santosh et al., 2009; Collins et al., 2007b). Coevally, along the northern margin of the SGT, broadly along the weak zones of paleosutures fringing the southern margin of the Dharwar Craton, an aborted rift formed along which several alkaline plutons were emplaced (Fig. 11a; Santosh et al., 2014).

Neoproterozoic crustal growth and recycling is evidenced from the extensive arc magmatism along the southern domain of the Madurai Block, following the earlier rifting of the Paleoproterozoic basement. The arc building was also associated with the accretion of shelf sediments that are now represented by the metasediments in the Trivandrum Block to the south (Fig. 11b, Santosh et al., 2017).

Multiple collisional events also occurred in the SGT, the earliest at $3.0 \mathrm{Ga}$ amalgamating the Coorg Block, followed by late Neoarchean-early Paleoproterozoic assembly of most of the northern crustal blocks, and the late Neoproterozoic-Cambrian collision along the PCSZ and the ACSZ.

\section{Mineralization}

Although the crustal collage in the SGT was built through subduction-accretion-collision process with a diversity of arc- a) Neoarchean arc-arc collision and arc-continent collision in southern India

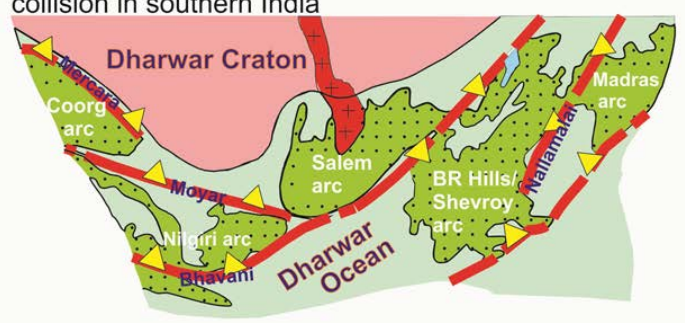

b) B.R. Hills slab melting, arc magmatism

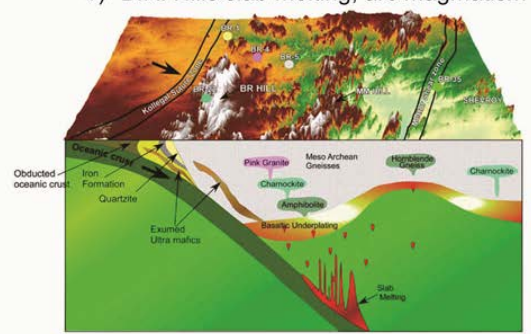

c) Subduction along the margin of Nilgiri Block and Agali ophiolite

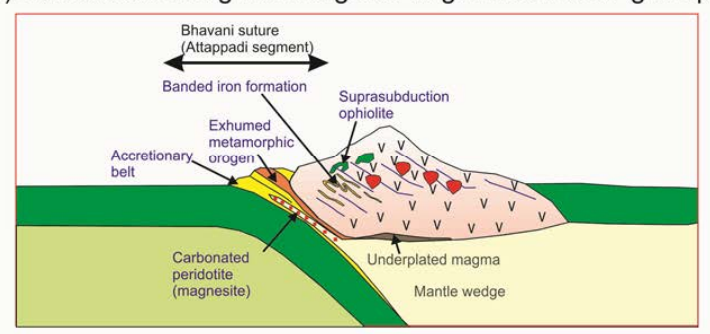

d) Arc-arc and arc-continent collision

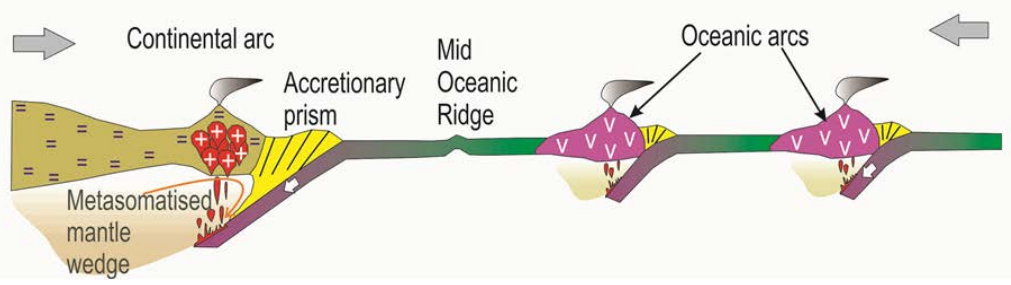

magmatic rocks, accreted shelf sequences and oceanic components, the high grade metamorphism, together with deep weathering and denudation have removed most of the potential mineralized zones. In most cases, the crystalline rocks are used as construction material or in polished stone industry. However, the gold mineralization in the Wynad gold belt, iron hosted within BIFs, voluminous metacarbonates as raw material for

Figure 10. Plate tectonic models of crust building in the Southern Granulite Terrane through subduction-accretion process. (a) Arc accretion along the southern margin of the Dharwar Craton (Santosh et al., 2013). (b) Slab subduction and melting model for the BR Hills Block (Ratheesh Kumar et al. 2016). (c) The Agali ophiolite as marker of subduction along the margin of the Nilgiri Block. (d) Schematic cartoon depicting continent growth through arc-arc, and arc-continent collision (Santosh et al., 2013). 
a) Cryogenian southern India

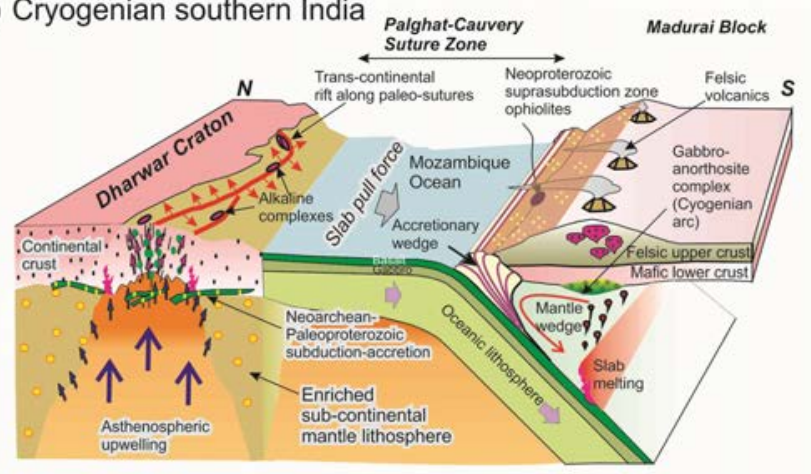

b) Evolution of Madurai Block

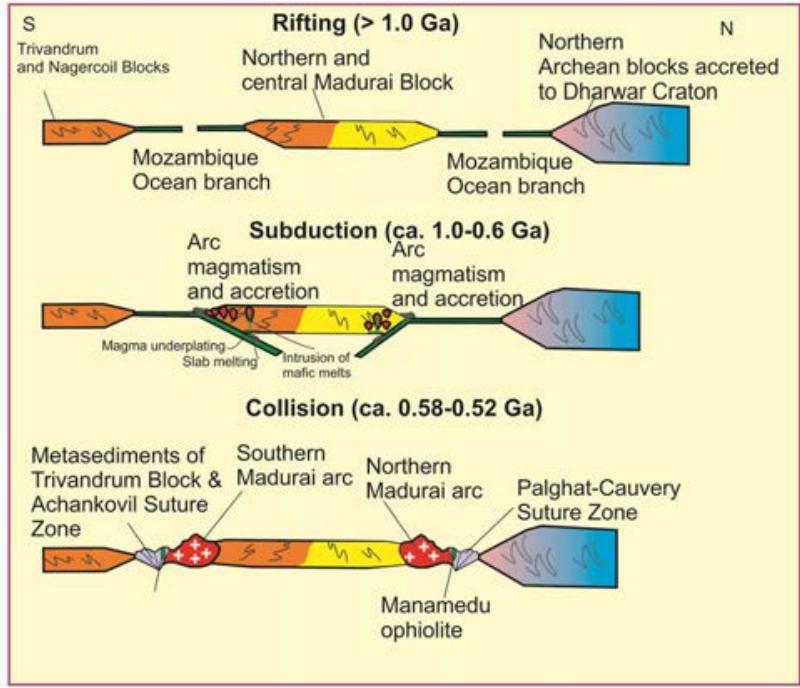

Figure 11. Plate tectonic models for Neoproterozoic tectonics in the Southern Granulite Terrane India with two examples. (a) Palghat-Cauvery Suture Zone region with southward subduction and rifting in the north (Santosh et al. 2014). (b) The Madurai Block in the Neoproterozoic with arc magmatism along the southern and northern margins (Santosh et al., 2017).

cement industry, possible PGE in the ultramafics, REE mineralization in alkaline intrusions, chromite and magnesite associated with altered ultramafics, the variety of gemstone mineralization in the KarurKangayam belt and in the Trivandrum Block, rare metals and rare earths in various pegmatites, the extensive heavy mineral beach placers along the western coast, and high grade clay deposits are among the various economic deposits in the SGT.

\section{Supercontinent connections}

Supercontinents are large land masses into which majority of the continental fragments of the globe are gathered into a tight assembly (Rogers and Santosh, 2002, 2004). The assembly, evolution and disruption of supercontinents through earth history have been frontier topics of research in earth sciences for several decades, as supercontinent cycles also exert major control on life evolution and environment (Nance et al., 2014, Meert and Santosh, 2017). The SGT has been central to the models on various supercontinents through time. The ancient continental nuclei, particularly those with Mesoarchean crust building history can be correlated to the oldest supercontinent on the earth, Ur. It is believed that the first coherent supercontinent on the globe was Columbia, which was assembled at around 2.0 to $1.8 \mathrm{Ga}$. Most of the southern crustal blocks in the SGT, up to the Nagercoil Block at the tip of the Peninsula, are characterized by Paleoproterozoic (ca. 2.0) basement rocks, implying that these were part of the Columbia supercontinent. There is not much evidence for the Neoproterozoic (1.0 Ga) Rodinia supercontinent history in the SGT, as against the clear "Grenvillian” imprint in some other terranes of Peninsular India. However, the most prominent imprint in the SGT, including within the PCSZ and in the blocks south of it, is the Late Neoproterozoic-Cambrian Gondwana assembly. The PCSZ is also considered as the trace of the Mozambique Ocean suture associated with the birth of Gondwana (Collins et al., 2007b). The major regime associated with Gondwana formation left significant imprints related to prolonged arc-type magmatism at the southern margin of the Madurai Block and elsewhere, and Cambrian metamorphism ranging up to ultra high temperature conditions in the various blocks. The history of disruption of Gondwana is also recorded in some of these crustal blocks in terms of mafic magmatism related to extension.

\section{Geophysical studies}

Numerous publications combining gravity, geoid, geothermal, seismic, magnetotelluric and other studies have been published on the crustal structure and mantle architecture of the SGT and adjoining regions. Most of these, however, are on a large scale, and lack the higher resolution for smaller domains to understand the geophysical architecture of individual crustal blocks and their intervening orogenic belts. A few examples of relevant studies are summarized below.

Kumar et al. (2013) presented 2-D lithospheric density modelling along three major transects of more than $1000 \mathrm{~km}$ in length each crossing the southern Indian shield, integrating topography, gravity and geoid anomalies, geothermal data, and available seismic data. Their modeling shows a crustal configuration with the Moho depth varying from $\sim 40 \mathrm{~km}$ beneath the Dharwar Craton, and $\sim 39 \mathrm{~km}$ beneath the SGT to about 15-20 km beneath the adjoining oceans (Fig. 12).The lithospheric thickness shows significant variation from 130-135 km under the southern part of the SGT including the adjacent Sri Lankan terrane, increasing gradually to $165-180 \mathrm{~km}$ beneath the northern part of the SGT and the Dharwar Craton. This lithosphere-asthenosphere boundary (LAB) shows step-like structure. Based on these results, the authors inferred a thickened crust, as well as a thin and hot lithosphere beneath the southern part of the SGT including Sri Lanka. They correlated the stretching and/or convective removal of the lower part of the lithosphere with tectonics associated with the late Neoproterozoic-Cambrian Gondwana assembly and Cretaceous mantle plume activity that introduced a hotter and lighter asthenosphere beneath the SGT. Ratheesh-Kumar et al. (2016) attempted to demarcate the spatial variation of crustal thickness of the blocks in the northern part of the SGT based on Moho configuration derived from flexure inversion analysis The results reveal higher crustal thickness in the Biligiri Rangan (BR) and the Nilgiri Blocks, and are attributed to a more thickened crust generated through the subduction of the western Dharwar crust. They identified distinct zones of high crustal thickness (deeper Moho) beneath Nilgiri Block ( 41 km), BR Block ( 38 km) and the Madurai Block. The BR Block shows crustal thinning $(\sim 33 \mathrm{~km})$ toward its eastern periphery. According to this study, the Western Dharwar Craton exhibits an average crustal thickness of about $35 \mathrm{~km}$. It is observed 


\section{a) Mantle and crustal strcuture}
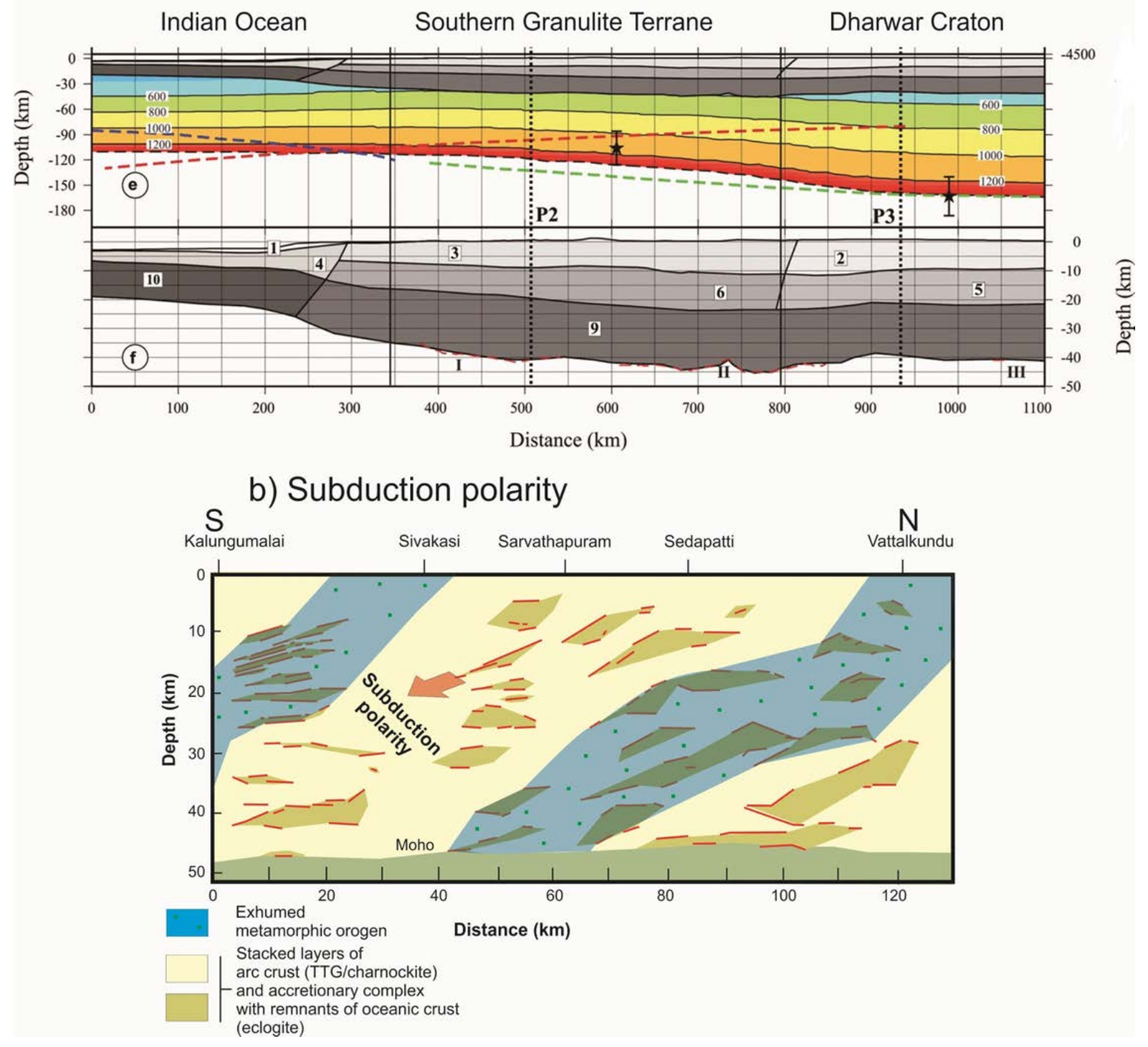

Figure 12. Representative geophysical interpretations. (a) Crustal and mantle structure of the southern part of the Dharwar Craton and the Southern Granulite Terrane (from Kumar et al., 2013, with the numerals and alphabets representing body boundaries and profiles as explained therein). (b) Subduction polarity interpreted from seismic reflection data (Naganjaneyulu and Santosh, 2011).

that the western Dharwar province adjacent to the BR Block has comparatively low crustal thickness ( $34 \mathrm{~km})$, and the Coorg Block to the south shows thinning of the crust (depth to the Moho $<32 \mathrm{~km}$ ). The Madurai Block also shows higher crustal thickness ( 35-40 km) whereas the PCSZ is marked by a distinct zone of low crustal thickness ( 32 km).

Naganjaneyulu and Santosh (2010) synthesized published geophysical data from gravity, seismic tomography, deep seismic sounding (DSS) and magnetotellurics (MT) to evaluate the architecture of the PCSZ and surrounding crustal blocks. They correlated the increased crustal thickness immediately north of the PCSZ to crustal thickening associated with subduction-collision processes during continental amalgamation. The marked gravity low of about - $45 \mathrm{~m}$ gal beneath Kodaikanal in the central Madurai Block, south of the PCSZ was inferred to represent the deep root of a thick magmatic arc. Deep seismic data from the central domain of the PCSZ show ca. $10 \mathrm{~km}$ thick low velocity $(6.0 \mathrm{~km} / \mathrm{s})$ layer at midcrustal depth. The two-dimensional MT model shows highly resistive felsic upper crust down to15-16 km. Integrating data from the various models, these authors identified a south dipping low resistive zone and a high density region at a depth range of $15-45 \mathrm{~km}$ within the central part of the PCSZ. They correlated the results to indicate subduction-collision-accretion tectonics along the PCSZ.

In another study, Naganjaneyulu and Santosh (2011) presented a magnetotelluric (MT) model covering the PCSZ in the north into the central part of the Madurai Block in the south. Integrating seismic reflection data along a $\mathrm{N}-\mathrm{S}$ transect further south within the Madurai Block, they evaluated the crustal architecture and its implications on the tectonic evolution of this region. The predominantly south dipping seismic reflectors beneath the Madurai Block with northward vergence was interpreted as a thrust sequence, representing imbricate structures or mega duplexes developed during subduction-accretion tectonics. A thick (>20 km) low resistivity layer 'floating' within high resistivity zone was imaged, suggesting the subduction of a moderately thick 
oceanic crust. The MT model also suggested eclogitised remnants of oceanic lithosphere. The seismic reflections and MT model were interpreted to represent southward subduction polarity with a progressive accretion history during the northward migration of the trench prior to the final collisional assembly of the crustal blocks along PCSZ.

\section{Concluding remarks}

The Southern Granulite Terrane with a diverse assemblage of Precambrian lithologies and as a window to deep crustal and crustmantle interaction processes, is one of the rare examples over the globe for integrated studies over the last four decades that expanded our knowledge base on various aspects of Earth history. These include early Earth evolution, formation, maturity, emergence and recycling of continental crust, convergent margin tectonics, arc magmatism, ultrahigh-temperature metamorphism, fluid-rock interaction processes, and supercontinent cycles. The SGT will continue to remain in focus not only for case studies related to lithology and structure, geophysical architecture, petrology, geochemistry, and isotope geochronology, but also for integrated tectonic models in understanding the formation and evolution of continental crust, crustmantle dynamics, as well as global correlations and connections.

\section{Acknowledgments}

I thank Dr. Saibal Gupta, Editor of the volume and an anonymous referee for constructive and helpful comments that helped in improving this paper. This work contributes to Foreign Expert position at China University of Geosciences Beijing, China and Professorial position at the University of Adelaide, Australia, of M. Santosh.

\section{References}

Bartlett, J.M., Dougherty-Page, J.S., Harris, N.B.W., Hawkesworth, C.J., Santosh, M.,1998. The application of single zircon evaporation and model $\mathrm{Nd}$ ages to the interpretation of polymetamorphic terrains: an example from the Proterozoic mobile belt of south India. Contributions to Mineralogy and Petrology 131, 181-195.

Bhaskar Rao, Y. J., Janardhan, A. 602 S., Vijaya Kumar, T., Narayana, B. L., Dayal, A. M., Taylor, P. N., and Chetty, T. R. K., 2003, Sm$\mathrm{Nd}$ model ages and Rb-Sr isotope systematics of charnockites and gneisses across the Cauvery Shear Zone, southern India: implications for the Archaean-Neoproterozoic boundary in the southern granulite terrain, in Ranmakrishnan, M., ed., Tectonics of Southern Granulite Terrain, Geological Society of India Memoir 50, p. 297-317.

Chacko, T.; Ravindra Kumar, G. R.; and Newton, R. C., 1987, Metamorphic P-T conditions of the Kerala (S. India) Khondalite belt, a granulite facies supracrustal terrain: Jour. Geology, v. 95, p. 343-358.

Chetty, T.R.K., Santosh, M., 2013. Proterozoic orogens in southern Peninsular India: Contiguities and complexities. Journal of Asian Earth Sciences 78, 39-53.

Chetty, T.R.K., Yellappa, T., Santosh, M., 2016. Crustal architecture and tectonic evolution of the Cauvery Suture Zone, southern India. Journal of Asian Earth Sciences 130, 166-191.

Clark, C., Collins, A.S., Timms, N.E., Kinny, P.D., Chetty, T.R.K., Santosh, M., 2009. SHRIMP U-Pb age constraints on magmatism and high-grade metamorphism in the Salem Block, southern India Gondwana Research 16, 27-36.

Collins, A.S.,Santosh, M.,Braun, I.,Clark, C., 2007a. Age and sedimentary provenance of the Southern Granulites, South India: $\mathrm{U}-\mathrm{Th}-\mathrm{Pb}$ SHRIMP secondary ion mass spectrometry. Precambrian Research 155, 125-138.

Collins, A. S., Clark, C., Sajeev, K., Santosh, M., Kelsey, D. E., and Hand, M., 2007b, Passage through India: the Mozambique Ocean suture, high-pressure granulites and the Palghat-Cauvery shear zone system: Terra Nova, v. 19, no. 2, p. 141-147.

Drury, S. A., and Holt, R. W., 1980, The tectonic framework of the South Indian craton: a reconnaissance involving LANDSAT imagery: Tectonophysics, 65,p. T1-T15.

Harley, S.L., 630 Santosh, M., 1995. Wollastonite at Nuliyam, Kerala: a reassessment of $\mathrm{CO} 2$ infiltration and charnockite formation at a classic locality. Contributions to Mineralogy and Petrology 20, 83-94.

Harris, N.B.W., Santosh, M., Taylor, P.N., 1994. Crustal Evolution in South India: Constraints from Nd Isotopes. Journal of Geology, 102, 139-150.

Johnson, T.E., Clark, C., Taylor, J.M., Santosh, M., Collins, A.S., 2015. Prograde and retrograde growth of monazite in migmatites: An example from the Nagercoil Block, southern India. Geoscience Frontiers 3, 373-387.

Kroner, A., Santosh, M., Hegner, E., Shaji, E., Geng, H., Wong, J., Xie, H., Wan, Y., Shang, C.K., Sun, M., Nanda-Kumar, V., 2015. Palaeoproterozoic ancestry of Pan-African high-grade granitoids in southernmost India: Implications for Gondwana reconstructions. Gondwana Research 27, 1-37.

Kumar, N., Zeyen, H., Singh, A.P., Singh, B., 2013. Lithospheric structure of southern Indian shield and adjoining oceans: integrated modelling of topography, gravity, geoid and heat flow data. Geophysical Journal International 194, 30-44.

Li, S.S., Santosh, M., Ganguly, S., Thanooja, P.V., Sajeev, K., Pahari, A., Manikyamba, C., 2017. Neoarchean microblock amalgamation in southern India:Evidence from the Nallamalai Suture Zone. Precambrian Research 314, 1-27.

Meert, J.G., Santosh, M., 2017. The Columbia supercontinent revisited. Gondwana Research 50, 67-83.

Naganjaneyulu, K., Santosh, M., 2010. The Cambrian collisional suture of Gondwana in southern India: A geophysical appraisal. Journal of Geodynamics 50, 256-267.

Naganjaneyulu, K., Santosh, M., 2011. Crustal architecture beneath Madurai Block,southern India deduced from magnetotelluric studies: Implications for subduction-accretion tectonics associated with Gondwana assembly. Journal of Asian Earth Sciences 40, 132-143.

Nance, R.D., Murphy, J.B. and Santosh, M., 2014. The supercontinent cycle: Aretrospective essay, Gondwana Research, 25, 4-29.

Plavsa, D.,Collins, A.S.,Payne, J.L.,Foden, J.D.,Clark, C., Santosh, M., 2014. Detrital zircons in basement metasedimentary protoliths unveil the origins of southern India. Geological Society of America Bulletin 126, 791-812.

Radhakrishna, B. P., 1989, Suspect tectono-stratigraphic terrane elements in the Indian subcontinent: Jour. Geol. Soc. India, v. 34, p. 1-24.

Radhakrishna, T., Joseph, M., 1996. Proterozoic palaeomagnetism of the mafic dyke swarms in the high-grade region of southern India. Precambrian Research 76, 31-46.

Raith, M., Karmakar, S., Brown, M., 1997. Ultra-high temperature metamorphism and multistage decompressional evolution of sapphirine granulites from the Palni hill ranges, Southern India. Journal of Metamorphic Geology 15, 379-99.

Rajesh, H.M., Santosh, M., 2004. Charnockitic magmatism in 
southern India. Proc.Indian Acad. Sci. (Earth Planet. Sci.), 113, pp. 565-585.

Rajesh, K.G., Chetty, T.R.K., 2006. Structure and tectonics of the Achankovil Shear Zone, southern India. Gondwana Research 10, 86-98.

Ram Mohan, M., Satyanarayanan, M., Santosh, M., Sylvester P.J., Tubrett, M., Lam, R., 2013. Neoarchean suprasubduction zone arc magmatism in southern India: Geochemistry, zircon U-Pb geochronology and Hf isotopes of the Sittampundi Anorthosite Complex. Gondwana Research 23, 539-557.

Ratheesh-Kumar, R.T., Santosh, M., Ishwar-Kumar, C.., Chen, N.S., Sajeev, K., 2016. Archean tectonics and crustal evolution of the Biligiri Rangan Block, southern India. Precambrian Research 275, 406-428.

Roberts, N.M.W., Santosh, M., 2018. Capturing the Mesoarchean Emergence of Continental Crust in the Coorg Block, Southern India. Geophysical Research Letters 45, 7444-7453.

Rogers, J.J.W. and Santosh, M., 2002. Configuration of Columbia, a Mesoproterozoic supercontinent, Gondwana Research, 5, 5-22.

Rogers, J.J.W. and Santosh, M., 2004. Continents and Supercontinents, Oxford University Press, Oxford, UK, 289 pp.

Sajeev, K., Osanai, Y., Santosh, M., 2004. Ultrahigh temperature metamorphism followed by two-stage decompression of garnetorthopyroxene-sillimanite granulites from Ganguvarpatti, Madurai block, southern India. Contributions to Mineralogy and Petrology 148, 29-46.

Samuel, V.O., Santosh, M., Liu, S.W., Wang, W., Sajeev, K., 2014. Neoarchean continental growth through arc magmatism in the Nilgiri Block, southern India. Precambrian Research 245, 146 173.

Santosh, M., 1996. The Trivandrum and Nagercoil granulite blocks. In: Santosh, M., Yoshida, M. (Eds.), The Archaean and Proterozoic terrains in southern India within East Gondwana. Gondwana Research Group, Memoir. 3, pp. 243-277.

Santosh, M., Drury, S.A., 1988. Alkali granites with Pan-African affinities from Kerala, S. India. Journal of Geology 96, 616-626

Santosh, M., Wada, H., 1993a. A Carbon Isotope Study of Graphites from the Kerala Khondalite Belt, Southern India: Evidence for CO2 infiltration in Granulites. The Journal of Geology, 101(5): 643-651.

Santosh, M., Wada, H., 1993b. Microscale isotopic zonation in graphite crystals: Evidence for channelled CO influx in granulites. Earth and Planetary Science Letters, 119(1-2): 19-26.

Santosh M, Harris N B W, Jackson D H and Mattey D P 1990. Dehydration and incipient charnockite formation: a phase equilibria 710 and fluid inclusion study from southern India. Journal of Geology 98, 915-926.

Santosh, M., Collins, A. S., Tamashiro, I., Koshimoto, S., Tsutsumi, Y., and Yokoyama, K., 2006. The timing of ultrahigh-temperature metamorphism in Southern India: U-Th-Pb electron microprobe ages from zircon and monazite in sapphirine bearing granulites: Gondwana Research, v. 10, no. 1-2, p. 128-155.

Santosh, M., Maruyama, S., and Sato, K., 2009, Anatomy of a Cambrian suture in Gondwana: Pacific-type orogeny in southern India? : Gondwana Research, v. 16, p. 321-341.

Santosh, M., Ram Mohan, M., Tsunogae, T., Shaji, E., Satyanarayanan, M., 2014.Cryogenian alkaline magmatism in the Southern Granulite Terrane, India: Petrology, geochemistry, zircon $\mathrm{U}-\mathrm{Pb}$ ages and $\mathrm{Lu}-\mathrm{Hf}$ isotopes. Lithos 208-209, 430-445.
Santosh, M., Shaji, E., Tsunogae, T., Ram Mohan, M., Horie, K., 2013. Suprasubduction zone ophiolite from Agali hill: Petrology, zircon SHRIMP U-Pb geochronology, geochemistry and implications for Neoarchean plate tectonics in southern India. Precambrian Research 231, 301-324.

Santosh, M., Tagawa, M., Taguchi, S., and Yoshikura, S., 2003a. The Nagercoil Granulite Block, southern India: petrology, fluid inclusions and exhumation history: Journal of Asian Earth Sciences, v. 22, p. 131-155.

Santosh, M., Yokoyama, K., Sekhar, S.B., Rogers, J.J.W., 2003b. Multiple tectonothermal events in the granulite block of southern India revealed from EPMA dating: implications on the history of supercontinents. Gondwana Res. 6, 29-63.

Santosh, M., Xiao, W.J., Tsunogae, T., Chetty, T.R.K., Yellappa, T., 2012. The Neoproterozoic subduction complex in southern India: SIMS zircon U-Pb ages and implications for Gondwana assembly. Precambrian Research 192-195, 190-208.

Santosh, M., Yang, Q.Y., Shaji, E., Tsunogae, T., Mohan, M.R., Satyanarayanan, M.,2015. An exotic Mesoarchean 739 microcontinent: the Coorg Block, southern India. Gondwana Research, 27(1): 165-195.

Santosh, M., Hu, C.-N., He, X.-F., Li, S.-S., Tsunogae, T., Shaji, E., Indu, G., 2017. Neoproterozoic arc magmatism in the southern Madurai Block, India: Subduction, relamination, continental outbuilding, and the growth of Gondwana. Gondwana Research, 45: 1-42.

Satish-Kumar M, Wada H and Santosh M 2002. Constraints on the application of carbon isotope thermometry in high to ultrahightemperature metamorphic terranes; Journal of Metamorphic Geology 20 335-350.

Shaji, E., Santosh, M., He, X.F., Fan, H.R., Dhanil Dev, S.G. Yang, K.F., Thangal, M.K., Pradeepkumar, A.P., 2014. Convergent margin processes during Archean- Proterozoic transition in southern India: Geochemistry and zircon U-Pb geochronology of gold-bearing amphibolites, associated metagabbros, and TTG gneisses from Nilambur. Precambrian Research 250, 68-96.

Shaji, E., Santosh, M., Li, S.S., Manikyamba, C., Tsunogae, T., Dhanil Dev, S.G., Panicker, A.G., Dhanakumar Singh, Th., Subramanyam, K.S.V., 2019. Buds of Santonian magmatism associated with Marion hotspot in southern India. Geological Journal 54, 31743187.

Shimpo, M., Tsunogae, T., Santosh, M., 2006. First report of garnetcorundum rocks from Southern India: implications for prograde high-pressure (eclogite-facies?) metamorphism. Earth and Planetary Science Letters 242, 111-129.

Srikantappa, C.,Raith, M.,Spiering, B., 1985. Progressive charnockitization of a leptynite- khondalite suite in southern Kerala, India - Evidence for formation of charnockites through decrease in fluid pressure? Journal of the Geological Society of India 26, 849-872.

Tateishi, K., Tsunogae, T., Santosh, M., Janardhan, A.S., 2004. First report of sapphirine+quartz assemblage from southern India: implications for ultrahigh-temperature metamorphism. Gondwana Research 7, 899-912.

Tsunogae, T., Santosh, M., 2010. Sapphirine + quartz assemblage from the Southern Granulite Terrane, India: diagnostic evidence for ultrahigh-temperature metamorphism within the Gondwana collisional orogen. Geological Journal, doi: 10.1002/gj.1244. 


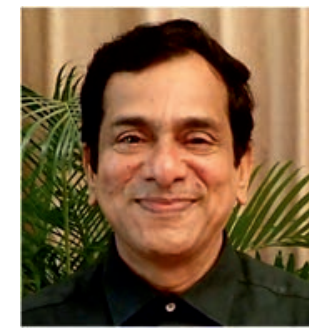

M. Santosh is Professor at the China University of Geosciences Beijing (China), Specially Appointed Foreign Expert of China, Professor at the University of Adelaide, Australia and Emeritus Professor at the Faculty of Science, Kochi University, Japan. PhD (Cochin University of Science and Technology, India), D.Sc. (Osaka City University, Japan) and D.Sc. (University of Pretoria, South Africa). He is the Founding Editor of "Gondwana Research" as well as the founding Secretary General of the International Association for Gondwana Research. Research fields include petrology, fluid inclusions, geochemistry, geochronology, metallogeny and supercontinent tectonics. Published over 1300 research papers, edited several memoir volumes and journal special issues, and co-author of the book 'Continents and Supercontinents' (Oxford University Press, 2004). Recipient of National Mineral Award, Outstanding Geologist Award, Thomson Reuters 2012 Research Front Award, Thomson Reuters High Cited Researcher 2014, 2015, 2016, 2017, 2018 and 2019. 